\title{
Trunk Injection to Deliver Crop Protection Materials: An Overview of Basic Principles and Practical Considerations ${ }^{1}$
}

\author{
Leigh Archer, Ute Albrecht, and Jonathan Crane ${ }^{2}$
}

\section{Introduction}

Trunk injection is a targeted delivery of crop protection materials into the stem or trunk of woody plants as an alternative to spraying or soil drenching. It is sometimes referred to as "endotherapy." Trunk injection occurs into the xylem of trees from where the injected material is distributed through the plant with the transpiration stream. There are several advantages that trunk injection provides over conventional spray or soil drenching of crop protection materials: (1) products are applied more precisely and used more efficiently; (2) spray drift is eliminated; (3) if properly applied there is a lower risk for worker exposure; and (4) nontarget organisms are less affected (Wise et al. 2014). Because there is less concern for human health and the environment, the method can be used in urban environments and residential areas where aerial sprays are not an option. Trunk injection is predominantly used in forested areas, landscapes, and nonagricultural areas. However, there is a long history of using plant injection to deliver crop protection to commercial avocado trees, e.g., phosphonate injection of avocado trees in Australia and South Africa (Dann et al. 2013). In the United States, most use in agricultural areas is in nonbearing crops, with Florida and California avocado trees being an exception. In California, injection of phosphonates to prevent phytophthora root rot has been implemented for decades. In Florida, approximately, $20 \%$ of the commercial acreage has been injected prophylactically to prevent (suppress) the laurel wilt pathogen (Raffaelea lauricola) on a 12-to-24month basis since 2014 (Crane et al. 2020).

The earliest evidence for plant injection is from the 12th century, when Arab horticulturists applied perfumes, spices, dyes, and other substances through wounds in plants to affect the smell, color, or other attributes of flowers and fruits (Roach 1939). The first documented experimentation on trunk injections is from the 15th century by Leonardo da Vinci (Roach 1939), who injected arsenic and other poisonous solutions in apple trees to poison the fruit, possibly to prevent thieves from stealing his fruits. Other experimentation until the early 1900s included injection of different nutrient solutions to overcome nutrient deficiencies and different organic and inorganic substances

1. This document is HS1426, one of a series of the Horticultural Sciences Department, UF/IFAS Extension. Original publication date November 2021. Visit the EDIS website at https://edis.ifas.ufl.edu for the currently supported version of this publication. The research for this article was supported with funds from USDA-NIFA-SCRI/CDRE \#2019-70016-29096.

2. Leigh Archer, graduate assistant; Ute Albrecht, assistant professor, Horticultural Sciences Department; UF/IFAS Southwest Florida Research and Education Center; and Jonathan Crane, professor, Horticultural Sciences Department, UF/IFAS Tropical REC; UF/IFAS Extension, Gainesville FL 32611.

The use of trade names in this publication is solely for the purpose of providing specific information. UF/IFAS does not guarantee or warranty the products named, and references to them in this publication do not signify our approval to the exclusion of other products of suitable composition.

All chemicals should be used in accordance with directions on the manufacturer's label.

The Institute of Food and Agricultural Sciences (IFAS) is an Equal Opportunity Institution authorized to provide research, educational information and other services only to individuals and institutions that function with non-discrimination with respect to race, creed, color, religion, age, disability, sex, sexual orientation, marital status, national origin, political opinions or affiliations. For more information on obtaining other UF/IFAS Extension publications, contact your county's UF/IFAS Extension office. U.S. Department of Agriculture, UF/IFAS Extension Service, University of Florida, IFAS, Florida A \& M University Cooperative Extension Program, and Boards of County Commissioners Cooperating. Nick T. Place, dean for UF/IFAS Extension. 
to control insect, fungal, and other diseases. An excellent review of these early studies is presented in Roach (1939), which details the history of plant injection, injection methods, and the physiology of the injection methods known at the time.

This overview focuses on trunk injection for delivering protection materials to agricultural crops to manage pests and diseases and discusses the underlying physiological principles and concerns associated with this method of delivery.

\section{Physiological Principles of Trunk Injection}

\section{Tree Anatomy}

The tree vascular system is composed of the xylem and the phloem. The xylem contains long, interconnected nonliving tubelike cells, the vessels or vessel elements, which transport water and nutrients from the roots through the rest of the tree. This transport is passive and occurs with the transpiration stream; its motor is the evaporation of water on the leaf surface (see next section). The xylem is the primary tissue through which trunk-injected materials are distributed throughout the tree. The arrangement of the xylem vessels affects how quickly and evenly injected materials spread through the tree. This is especially evident when comparing hardwood trees (angiosperms) and softwood trees (gymnosperms), which differ greatly in their vessel arrangement.
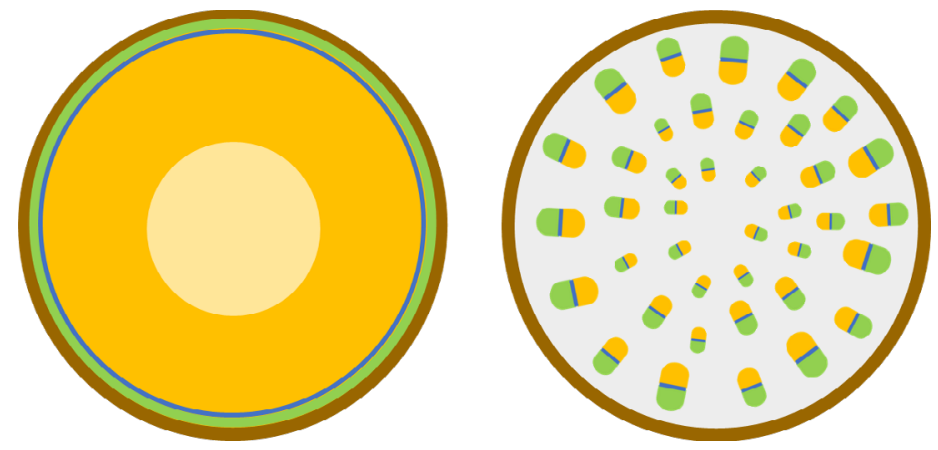

Figure 1. Schematic cross section of a woody tree trunk (left) and a palm trunk (right). Brown = outer bark, green = phloem, blue = vascular cambium, yellow $=$ xylem, light yellow $=$ heartwood. Credits: Ute Albrecht, UF/IFAS

The phloem is composed of living cells, the sieve cells, which form tubes in which dissolved sugars are transported away from photosynthesizing leaves (source) to sink organs such as roots and developing fruits. In the stem of dicotyledonous plants such as trees, the phloem is a thin band of tissue between the bark and the vascular cambium, while the xylem comprises most of the stem underneath the cambium. In monocotyledonous treelike plants, such as palms, phloem and xylem are arranged in bundles that are dispersed within the trunk. Therefore, the distribution and efficacy of injected materials is different compared to woody trees.

\section{Water Movement in Trees}

How water naturally moves through a tree provides insight on how crop protection materials are distributed after being injected into the trunk. Water movement in the xylem of plants occurs through a negative hydrostatic pressure created by the evaporation of water (transpiration) on the leaf surfaces. This suction-like force pulls the water from the roots and up through the trunk and branches to the leaves. The water within each xylem vessel can be thought of as a long column that is under strong tension. This column is held together because of the special cohesive properties of water.

Trunk injection forces the injected compound into the xylem vessels, where it is pulled upward and distributed throughout the canopy of the tree. However, drilling, or boring holes for injection, causes xylem vessels to embolize. This means that the tension of the water column breaks, and the vessel fills with air and become dysfunctional. In addition to causing vessels to embolize, the mechanical injury imposed by drilling or boring generates a wound and a tree stress response. The impact of these responses varies with the type of injection device used, tree characteristics, material formulation, and environmental conditions.

\section{Tree Wound Repair}

Trees are generally very effective at compartmentalizing wounds and blocking decay-causing organisms, mostly fungi and bacteria, from spreading. The cells responsible for wound compartmentalization are the xylem parenchyma cells, living cells that surround the nonliving vessel elements and are arranged in radial and tangential bands. In response to wounding, parenchyma cells surrounding the wound site produce phenolic and other substances that are toxic to the invading organisms. The cells suberize and become impervious to fluid diffusion. Because of the regular raylike arrangement of parenchyma cells (ray parenchyma), wound compartmentalization is most effective in the tangential (left-to-right) direction. Compartmentalization in the radial direction is also effective, but less so than in the tangential direction. The arrangement of the parenchyma cells is species-specific and determines the efficacy of wound compartmentalization. 
It is much more difficult to control decay from spreading in the vertical direction because of the length of the xylem vessels and the speed of the transpiration stream. Compartmentalization in the vertical direction occurs through tyloses, which are balloon-like invaginations of the parenchyma cells surrounding the vessels. These plug the vessels above and below the wound site and prevent collapse of the transpiration stream as well as spread of invading organisms. After wounding, the cambium cells near the wound site start to divide, closing the wound and producing new vascular tissue outside of the wound.

The compartmentalization or healing of wounds depends on the plant species, wound depth and size, the time of the year, and the properties of the injected compound. Wounds heal faster during spring and summer, when trees are metabolically more active than during fall and winter. Also, wounds heal faster when they occur in the outer rings of the xylem (the sapwood) because these are metabolically more active than the inner rings. Some crop protection materials (e.g., oxytetracycline) can exert phytotoxic effects which prevents wound healing. When using trunk injection to protect agricultural crops, it is therefore important to determine crop-specific anatomical and physiological characteristics and determine potential phytotoxic effects of the material to be injected before commencing on a large scale.
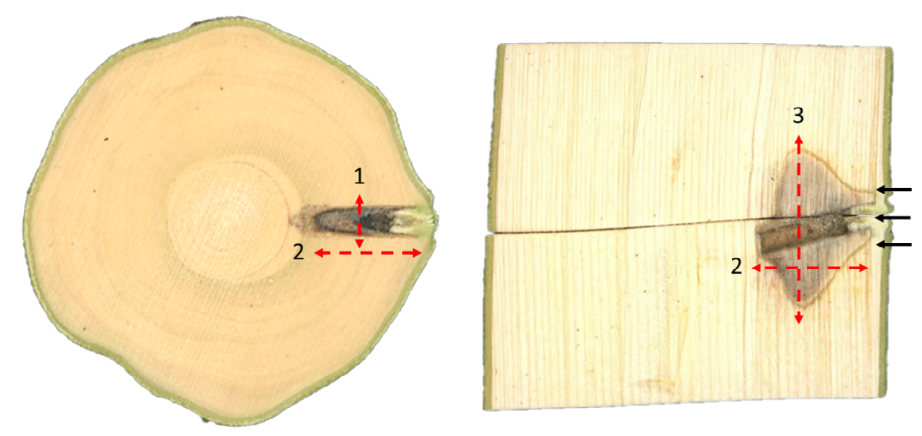

Figure 2. Cross section (left) and longitudinal (right) section of a tree injected with water. The wound caused by the injection is more effectively contained in the tangential (1) and radial (2) direction than in the vertical direction (3). Note the healthy tissue produced during the next growing season covering the wound site (black arrows). Credits: Leigh Archer and Ute Albrecht, UF/IFAS

\section{Trunk Injection Methods}

Many different injection devices by which materials can be injected with different degrees of pressure are commercially available. High-pressure injection usually occurs through injectors that are attached via tubing to a portable canister filled with compressed gas (air or nitrogen). Low-pressure injection and passive infusion typically do not require a compressed air canister or other peripheral features.

\section{High-Pressure Injection}

The ArborJet Quik-Jet Air (ArborJet Inc, MA, Woburn, USA), is one example of a high-pressure injection device. This system uses $7.15 \mathrm{~mm}$ or larger diameter plastic plugs, which are inserted into the tree after drilling a hole. The plugs create a tight seal for injection, prevent leaking, and reportedly protect the wound from pathogens and insects. Injection of the compounds occurs through these injection plugs at pressures of 60-100 psi and requires compressed gas. Although the plugs enable the rapid injection of large volumes of material, they increase the size of the injection hole and, if left in place, interfere with the natural healing of the wound.
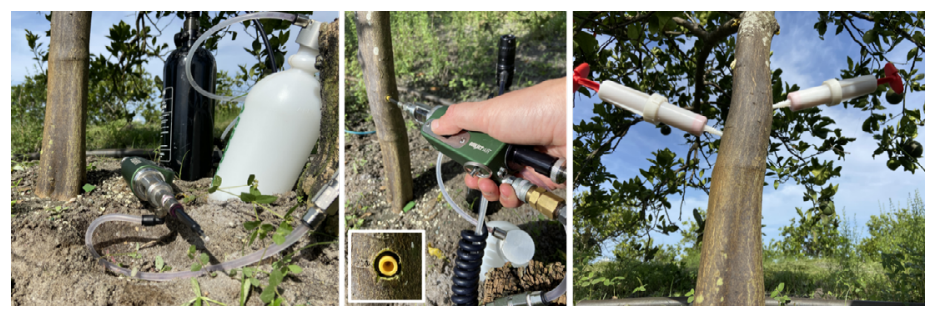

Figure 3. Equipment needed for high-pressure injection (left). Highpressure injection requires a plastic plug, which may remain in the tree after injection (center). Medium-pressure injection using a springloaded syringe that is removed after the material has been taken up (right).

Credits: Leigh Archer, UF/IFAS

\section{Low-Pressure Injection}

Alternatives to high-pressure injection are various syringeor needle-based methods, sold by Chemjet (Kerrville, TX USA), Mauget (Arcadia, CA), Rainbow Treecare (Minnetonka, $\mathrm{MN}$ ), and other manufacturers, that do not require a plug. Injection occurs at lower pressures $(<60$ psi) by manual squeezing or pumping, or automatically by a spring-loaded mechanism. Similar systems can be made through purchasing and assembling the necessary injection port parts (Crane et al. 2014). Tree uptake is slower due to the lower pressure; however, the smaller injection port size and absence of a permanent plug usually allow for quicker wound repair.

\section{No-Pressure Injection (Infusion)}

Implanted capsules such as the Acecap (Creative Sales Inc, NE USA), are no-pressure devices inserted into a drilled hole. Uptake of materials is through the natural transpiration-driven movement of sap in the tree and is greatly influenced by the ambient weather conditions and soil moisture available. Methods relying on passive infusion are slower and may not efficiently distribute materials. Once placed, these devices stay in the tree indefinitely, where they will be compartmentalized. Alternatively, a simple passive infusion system may be constructed using a disposable 
$1500 \mathrm{ml}$ enema bag, tubing, and other necessary infusion port parts (Crane et al. 2014).
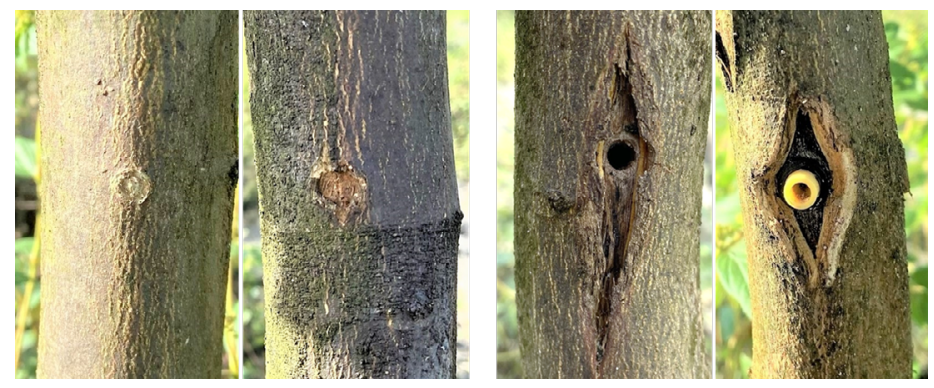

Figure 4. Wounds induced by low-pressure injection generally heal well and close completely (left). Wounds induced by injection of some materials (here oxytetracycline) and by high-pressure injection may not close and often result in extensive bark cracking (right).

Credits: Leigh Archer, UF/IFAS

\section{Physiological Implications of Trunk Injection}

Higher pressure can increase the speed and volume of liquid taken up by the tree compared to lower pressure. However, this will increase the external and internal damage to the tree, and this risk needs to be assessed for each crop system.

\section{Drilled-Based vs. No-Drill Injection}

The greatest threat associated with a larger wound size is girdling the tree trunk or branches, especially when performing multiple or repeated injections. Smaller-diameter injection devices can be expected to reduce the likelihood of girdling. Drill injection causes the most wounding but is most widely used because liquids can be delivered more rapidly and in larger quantities than when using blades or needles.

\section{High-Pressure vs. Low- or No-Pressure Injection}

No-pressure systems may limit the volume of material that can be applied within a short time, while high-pressure systems increase the risk of vessel cavitation and girdling.

Pressurized devices allow for relatively large quantities of product to be injected into a tree in a short period of time. The extent and consequences of the physiological damage inflicted on the tree due to the high pressure needs to be established for each tree system. Injection systems with removable injection ports generally cause less damage and heal more quickly than systems where the ports are left in the tree. Implant-based injection devices are left in the tree indefinitely to slowly release compounds. The phytotoxic effects of this method for injection can be more severe because of the extended contact time between the chemical products and tree tissues.

Whether high- or low-pressure systems are used, the toxicity of the solution used may influence the extent of damage to the tree at or near the infusion or injection ports. In some instances, the wound caused by the injection ports does not heal well and allows wood-rooting organisms to invade the area, causing lasting wounds. Removable injection ports and technologies that reduce the size of an injection port but use a high-pressure approach have been developed for commercial avocado operations in Florida, although they are proprietary. Similar systems may need to be developed before injection methodologies can be adopted in other commercial tree-crop production systems.

\section{Trunk Injection to Control Pests and Diseases}

Trunk injection has been used to combat many different pests and diseases, including fungal and bacterial pathogens, chewing and sap-sucking insects, and wood-boring insects and nematodes. Modern research on injection has generally coincided with outbreaks of catastrophic tree diseases or pests.

\section{Fungal and Oomycete Diseases}

Modern research on trunk injection began in response to the catastrophic spread of Dutch Elm Disease (DED) caused by the fungal pathogen Ophiostoma novo-ulmi and spread by elm bark beetles (Hylurgopinus rufipes and Scolytus sp.). Fungicide injections have been used both preventatively and retroactively to reduce the impact of DED. Registered fungicides include propiconazole (such as Shepard by Arborsystems or Alamo by Rainbow Treecare, among others) or thiabendazole hypophosphite (Rainbow Treecare "Arbotect 20S").

In commercial avocado production trunk injection of fungicides has been used for decades. Historically, injection was primarily used for phytophthora management; however, the spread of laurel wilt (LW), caused by the fungus Raffaelea lauricola and spread by redbay ambrosia beetles, across the natural areas of the southeastern United States incited interest in managing this disease through trunk injection. LW is now endemic in Florida's avocado production area (primarily Miami-Dade County) and spread among avocado tree root grafts by at least four ambrosia beetle species (Crane et al. 2020). Currently, injection for laurel wilt management occurs on about $20 \%$ of the 
commercial acreage ( $\sim 6,000$ acres), and one formulation of propiconazole $\left(\mathrm{Tilt}^{\star}\right)$ is currently registered for this use.

\section{Insect Pests and Nematodes}

The devastating outbreak of the emerald ash borer (Agrilus planipennis) was a trigger for advancing injection technologies for managing insect pests. The emerald ash borer is an insect that burrows and feeds beneath the bark and causes nearly $100 \%$ mortality of ash trees. Emamectin benzoate (such as Tree-age by Arborjet or Mectinite by Rainbow Tree Care) and imidacloprid (such as Pointer by Arborsystems or Imicide by Mauget) are two insecticidal formulations that are labeled for injection against the emerald ash borer.

The pine wood nematode (Bursaphelenchus xylophilus) vectored by the pine sawyer beetle (Monochamus sp.) is the causal agent of the devastating pine wilt disease. Injections of emamectin benzoate and abamectin have been successful in managing the nematode. However, the widespread adoption of trunk injection for insect management in commercial crops has been limited due to time and labor costs associated with this delivery method.

\section{Bacterial and Phytoplasma Diseases}

Bacterial diseases can be particularly difficult to control because bacteria reproduce rapidly, can be spread by wind, rain, insects, or other animals, and often reside in tissues inside the plant such as the leaf subcellular space or the vascular system.

Fire blight is a devastating bacterial disease of apples, pears, and other pome fruits caused by Erwinia amylovora. Researchers have begun exploring the efficacy of trunkinjected antibiotics for fire blight management. At the commercial scale, injection as a management technique remains impractical; however, there have been studies that demonstrated the higher efficacy of injection over spray applications.

Currently the most extensive use of antibiotics for trunk injection is for control of lethal-yellowing-type phytoplasmas in palms. Lethal yellowing (LY) and, more recently, lethal bronzing (LB) are diseases associated with phloemlimited phytoplasmas (bacteria-like organisms) that affect many different palm species. The antibiotic oxytetracycline hydrochloride (OTC-HCl) has been used both preventatively and curatively for management of LY in palms and has only shown efficacy when applied through injection but not through soil drenches or foliar sprays (McCoy 1982).
The use of trunk injections for widespread containment and management of LY-type phytoplasmas in palms can be seen as a model for the utility of trunk injection techniques to manage vascular diseases. However, as mentioned previously, the vascular arrangement of palms and trees species differs greatly, and it is unclear how effective trunk injections will be to manage phloem diseases in the latter.

Huanglongbing (HLB), or citrus greening, is a devastating disease associated with bacteria in the genus Candidatus Liberibacter spp. and spread through psyllids. HLB of citrus is similar to LY and LB of palms in that the pathogens are vector-transmitted and reside in the phloem. Because of the devastation HLB has wreaked on the Florida citrus industry since its discovery in 2005 , there has been great interest in managing the disease by applying antibiotics such as oxytetracycline via trunk injection.

Tree Tech ${ }^{\otimes}$ OTC is an oxytetracycline calcium complex registered for use in crop-bearing peaches and pears for bacterial blast, blossom blight, and fire blight management, and X-disease of peaches. There are few other bactericides registered for injection in crop-bearing trees. At the experimental level, however, several bactericides have been tested for trunk injection to manage diseases in different crops (Table 1).

\section{Other Considerations}

The chemical property and formulation of an injected compound determine its ability to move within the tree. The chemical structure dictates its ability to either move across cell membranes or bind to cell walls or other cell components. Most mobile compounds will preferentially move through the xylem but may not transfer to or move readily in the phloem. Formulation of the active ingredient is crucial for quick and even distribution of the chemical. Considering both the location of the target organism and the physical/chemical properties of injected materials is critical for understanding physiological effects on the tree and for predicting the efficacy of injections.

The location of the injection port needs to be determined for each crop system to minimize wounding and promoting efficient distribution throughout the tree. ArborJet, ChemJet, and many other systems recommend injecting into the base of the tree or the root flares. However, these recommendations are for disease management in forest trees and large ornamental species, where access to scaffold branches is difficult. Injection into other parts of the tree in commercially grown fruit tree crops is possible but needs to 
be studied carefully to minimize wounding and decay while maximizing uptake and distribution.

The best time of the day or season for injection has been established for some but not all tree systems. In general, the speed of compound uptake and distribution after trunk injection increases with the rate of transpiration. Conditions that enhance transpiration are therefore recommended for efficient uptake and distribution of injected materials. For deciduous trees in temperate climates, late spring and summer will be most ideal to ensure upward movement due to the higher rates of transpiration. Fully watered trees, warm temperatures, and slightly windy conditions can also enhance transpiration and therefore increase the uptake rate of injected materials. The residual activity of the crop protection material in combination with the disease cycle also need to be determined for each crop-pathosystem.

There are many different types of crop protection materials and nutritional products available for trunk injection, and it is crucial to follow label directions. One important concern when using trunk injection to deliver crop protection materials is their level of residue concentrations in the fruits. Currently, trunk injection as a delivery method for crop protection materials is labeled mostly for use on ornamental trees or nonbearing crops and rarely for bearing crops. Other considerations concern the potential support of the pest control manufacturer and determination by the EPA that the material has a chance for registration for use in a food crop. If either entity does not support the proposal, even with substantial efficacy and phytotoxicity data available, the product will not be registered for use.

\section{References}

Acimovic, S. G., G. C. McGhee, G. W. Sundin, and J. C. Wise. 2015. "Evaluation of Trunk-Injected Bactericides and Prohexadione-Calcium for Environmentally Friendly Control of Fire Blight (Erwinia amylovora) in Apples." Proc. 7th Congress Plant Prot. 129-134.

Acimovic, S. G., Q. Zeng, G. C. McGhee, G. W. Sundin, and J. C. Wise. 2015. "Control of Fire Blight (Erwinia amylovora) on Apple Trees with Trunk-Injected Plant Resistance Inducers and Antibiotics and Assessment of Induction of Pathogenesis-Related Protein Genes." Front. Plant Sci. 6:16. https://doi.org/10.3389/fpls.2015.00016

Amanifar, M. T., and M. Salehi. 2016. “Xylella fastidiosa from Almond in Iran: Overwinter Recovery and Effects of Antibiotics." Phytopatho. Mediterr. 55 (3): 337-345. https:// doi.org/10.14601/Phytopathol_Mediterr-17682
Cooley, D. R., T. A. Tattar, and J. T. Schieffer. 1992.

"Treatment of X-disease of Peaches Using Oxytetracycline Microinjection Capsules." HortScience 27 (3): 235-237. https://doi.org/10.21273/HORTSCI.27.3.235

Crane, J. H., D. Carrillo, E. A. Evans, R. Gazis, B. Schaffer, F. Ballen, and J. Wasielweski. 2020. "Current Recommendations for Control of Laurel Wilt and Its Ambrosia Beetle Vectors in Florida’s Commercial Avocado Groves." Proc. Fla. State Hort. Soc. 133:4-6.

Crane, J. H., W. Montás, E. A. Evans, and R. Olszack. 2014. "How to Make a Simple and Inexpensive Passive and Pressurized Infusion System for Systemically Applied Pest Control Substances to Fruit Trees." Proc. Fla. State Hort. Soc. 127:6-9.

Crane, J. H., R. C. Ploetz, T. White, G. C. Krogstad, T. Prosser, J. Konkol, and R. Wideman. 2015. "Efficacy of Three Microinfused Fungicides to Control Laurel Wilt on Avocado in Martin and Brevard Counties." Proc. Fla. State Hort. Soc. 128:58-60.

Dann, E. K., R. C. Ploetz, L. M. Coates, and K. G. Pegg. 2013. "Foliar, Fruit and Soilborne Diseases." In The Avocado: Botany, Production and Uses (2nd edition), edited by B. Schaffer, B. N. Wolstenholme, and A. W. Whiley, 380-422. Oxfordshire, UK: CAB International. https://doi. org/10.1079/9781845937010.0380

Harrison, N. A., and M. L. Elliott. 2008. "Lethal Yellowing of Palms." The Plant Health Instructor. https://doi. org/10.1094/PHI-I-2008-0714-01

Hu, J., and N. Wang. 2016. "Evaluation of the Spatiotemporal Dynamics of Oxytetracycline and Its Control Effect against Citrus Huanglongbing via Trunk Injection.” Phytopathol. 106 (12): 1495-1503. https://doi.org/10.1094/ PHYTO-02-16-0114-R

McCoy, R. E. 1982. "Use of Tetracycline Antibiotics to Control Yellows Diseases.” Plant Disease 66:539-542. https://doi.org/10.1094/PD-66-539

Ploetz, R. C., J. M. Pérez-Martínez, E. A. Evans, and S. A. Inch. 2011. "Toward Fungicidal Management of Laurel Wilt of Avocado." Plant Disease 95 (8): 977-982. https://doi. org/10.1094/PDIS-08-10-0595 
Puttamuk, T., S. Zhang, Y. Duan, A. Jantasorn, and N. Thaveechai. 2014. "Effects of Chemical Treatments on 'Candidatus Liberibacter asiaticus' Infected Pomelo (Citrus maxima)." Crop Prot. 65:114-121. https://doi.org/10.1016/j. cropro.2014.07.018

Reil, W. O. 1979. "Pressure-Injecting Chemicals into Trees." Calif. Agric. 22:16-19.

Roach, W. A. 1939. "Plant Injection as a Physiological Method." Ann. Bot. 3 (1): 155-226. https://doi.org/10.1093/ oxfordjournals.aob.a085050

Rumbos, I. 1986. "Control of Apricot Chlorotic Leaf Roll with Pressure Injecting Antibiotics." ISHS Acta Hortic. 192:175-182. VIII Int. Symp. Apricot Cult. Decline. https:// doi.org/10.17660/ActaHortic.1986.192.28

Shin, K., M. S. Ascunce, H. A. Narouei-Khandan, X. Sun, D. Jones, O. O. Kolawole, E. M. Goss, and A. H. C. van Bruggen. 2016. "Effects and Side Effects of Penicillin Injection in Huanglongbing Affected Grapefruit Trees." Crop Prot. 90:106-116. https://doi.org/10.1016/j.cropro.2016.08.025

Wise, J. C., A. H. VanWoerkom, S. G. Acimovic, G. W. Sundin, B. M. Cregg, and C. Vandervoort. 2014. “Trunk Injection: A Discriminating Delivering System for Horticulture Crop IPM." Entomol. Ornithol. Herpetol. 3 (2): 100126. https://doi.org/10.4172/2161-0983.1000126

Yang, C., C. A. Powell, Y. Duan, R. Shatters, Y. Lin, and M. Zhang. 2016. "Mitigating Citrus Huanglongbing via Effective Application of Antimicrobial Compounds and Thermotherapy." Crop Prot. 84:150-158. https://doi. org/10.1016/j.cropro.2016.03.013 
Table 1. Published studies regarding the efficacy of trunk injections for bacterial and phytoplasma disease management.

\begin{tabular}{|c|c|c|c|c|}
\hline Crop Species & Pest/Disease & Antibiotic & $\begin{array}{l}\text { Efficacy of Trunk } \\
\text { Injection }\end{array}$ & Reference \\
\hline Almond (Prunus dulcis) & $\begin{array}{l}\text { Almond leaf scorch (Xylella } \\
\text { fastidiosa) }\end{array}$ & Oxytetracycline, penicillin & Effective & Amanifar et al. 2016 \\
\hline Apple (Malus domestica) & $\begin{array}{l}\text { Fire blight (Erwinia } \\
\text { amylovora) }\end{array}$ & $\begin{array}{l}\text { Copper chelate, } \\
\text { kasugamycin, } \\
\text { oxytetracycline }\end{array}$ & Effective & $\begin{array}{l}\text { Acimovic, McGhee, et al. } \\
2015\end{array}$ \\
\hline Apple (Malus domestica) & $\begin{array}{l}\text { Fire blight (Erwinia } \\
\text { amylovora) }\end{array}$ & Streptomycin & Effective & Acimovic, Zeng, et al. 2015 \\
\hline $\begin{array}{l}\text { Apricot (Prunus } \\
\text { armeniaca) }\end{array}$ & Apricot leaf roll disease & Oxytetracycline & Effective for one season & Rumbos 1986 \\
\hline $\begin{array}{l}\text { Avocado (Persea } \\
\text { americana) }\end{array}$ & $\begin{array}{l}\text { Laurel wilt (Raffaelea } \\
\text { lauricola) }\end{array}$ & Propiconazole $\left(\right.$ Tilt $^{\circledR}$ ) & Effective for $12-14$ months & $\begin{array}{l}\text { Ploetz et al. 2011; Crane et } \\
\text { al. } 2015\end{array}$ \\
\hline $\begin{array}{l}\text { Grapefruit (Citrus } \\
\text { paradisi) }\end{array}$ & Huanglongbing & Penicillin & Effective & Shin et al. 2016 \\
\hline $\begin{array}{l}\text { Grapefruit (Citrus } \\
\text { paradisi) }\end{array}$ & Huanglongbing & Ampicillin & Effective & Yang et al. 2016 \\
\hline Palm (Aracaceae sp.) & $\begin{array}{l}\text { Lethal Bronzing } \\
\text { (Phytoplasma palmae) }\end{array}$ & Oxytetracycline & $\begin{array}{l}\text { Effective as preventative } \\
\text { measure only }\end{array}$ & Harrison and Elliott 2008 \\
\hline Peach (Prunus persica) & $\begin{array}{l}\text { Peach X-disease } \\
\text { (Mycoplasma sp.) }\end{array}$ & Oxytetracycline & Effective & Cooley et al. 1992 \\
\hline Pear (Pyrus calleryana) & Pear decline & Terramycin & Effective in combination & Reil 1979 \\
\hline Pomelo (Citrus maxima) & Huanglongbing & $\begin{array}{l}\text { Streptomycin + penicillin } \\
+ \text { ampicillin }\end{array}$ & Effective & Puttamuk et al. 2014 \\
\hline $\begin{array}{l}\text { Sweet orange (Citrus } \\
\text { sinensis) }\end{array}$ & Huanglongbing & Oxytetracycline & Effective & Hu and Wang 2016 \\
\hline
\end{tabular}

